\title{
Las fantasías de Hawthorne
}

Prólogo y traducción de los Cuadernos americanos

POR C. E. Zavaleta

$P R O L O G O$

Las páginas que siguen dan al lector unos fragmentos de los Cuadernos americanos, de Nathaniel Hawthorne, abreviados ya desde la primera edición en 1868, cuando su viuda publicara también unos "pasajes". En verdad, Sophia Amelia Peabody modificó el texto por bañar aún más de decoro al circunspecto Hawthorne, debido a cierto refinamiento posterior a la cruel Guerra de Secesión. Por fortuna, Pen 1932, Randall Stewart transcribió con fidelidad estos bocetos de cuentos y novelas, respetados a su vez por Malcolm Cowley en la popular antología The Portable Hawthorne*, donde hay una breve selección de ellos, que yo ahora traduzco parcialmente.

Escritor norteamericano nacido en 1804 y muerto en 1864 , Hawthorne no es muy conocido por nosotros. Si bien desde 1840 algunos de sus cuentos se traducen al español, en gran parte de América Latina y España es apenas el autor de La letra escarlata, novela de una mujer condenada a llevar la letra $A$ en el pecho, en señal de haber cometido un adulterio, y de contados cuentos de "atmósfera sobrenatural y moral", según dicen los

- The Portable Hawthorne. Edited, with an Introduction and Notes, by Malcolm Cowley (New York: The Viking Press, 1948), pp. 547-572. 
anónimos propagandistas de las editoriales, cuentos divulgados por colecciones como las de Jackson y Austral.

Así, poco sabemos de sus cuatro volúmenes de relatos, de sus otras novelas (él las llamó "romances"), y de cuatro novelas más, inconclusas, sin contar los cuadernos de notas sobre sus viajes por Estados Unidos, Inglaterra, Francia e Italia, ni mencionar sus cuentos para niños o un verdadero Libro de maravillas, así titulado por él.

Hawthorne vivió el calvinismo puritano de las ya libres colonias inglosas en América. Narrador más o menos objetivo, prefería, no obstante, el tema de los efectos psicológicos del pecado sobre los creyentes o del vacío moral forjado por la inteligencia. En su época, se ha dicho, la moral pasaba de la conciencia sectaria a la imaginación y ganaba sutiles formas del simbolismo, razón que eleva su obra de una esfera provincial a otra universal.

Hawthorne está así en medio de una batalla entre fuerzas literarias y extraliterarias, las ultimas representadas por la ética y la religión. A menudo sus cuentos (planeados en forma de los argumentos de esta traducción), renuncian al meollo temático y narrativo, pintan alegorías y hasta resumen lo descrito en moralejas que apagan el fuego brillante y sorpresivo de las situaciones planeadas. El tema de "Wakefield", por ejemplo, es fascinador de por sí: un hombre hace maletas para un gran viaje y se despide de su mujere pere alquila una habltación a la vuelta de la esquina, donde por veinte años vive como un desconocido, observando a su mujer y a su propia casa; y vuelve después de esos años, como si hublera salido horas antes. El cuento, que pudo ser lineal y unitario, se llena de interpolaciones del autor, de adelantos y retrocesos narrativos, y finaliza con esta moraleja: "En el desorden aparente de nuestro misterioso mundo, cada hombre está ajustado a un sistema con tan exquisito rigor -y los sistemas entre sí, y todos a todo- que el individuo que se desvía un solo momento, corre el terrible albur de perder para slempre su lugar. Corre el albur de ser, como Wakefield, el Paria del Universo"." * Otro de los cuentos más difundidos, "La hija de Rap-

* Este y otros pasajes traducidos por Jorge Luis Borges constan en la segunda edición del libro Otras inquisiciones (1937-1952) (Buenos Aires: Sur, 1952), y forman parte del excelente ensayo "Nathaniel Hawthorne." 
paccini", exhibe demasiado la alegoría del hombre de ciencia que sacrifica a su hija en inhumanos experimentos, a pesar de que la narración se funda, de algún modo, en el atroz y bello argumento de Sir Thomas Browne que aparece en estos Cuadernos y que no debió perder la concisión ni el luminoso remate:

Una historia se contaba de un rey de la India que envió a Alejandro una hermosa mujer alimentada con acónito y otros venenos, para destruirlo fisiológicamente, ya sea por medio de la plática o de la copulación.

Hay, es claro, cuentos cabales. No obstante la aparición de un diablo y de espíritus del mal en un bosque, "El joven Goodman Brown" defiende menos una tesis moral que una situación poética, en la cual Goodman (hombre bueno, según reza su nombre) descubre, ya en la realidad o en un sueño, que su virtuosa mujer llamada Fe no es o no será digna, y se trastorna y aleja de los hombres, descubrimiento posible merced a la "percepción instintiva del alma humana", de que nos habla Harwthorne. Luego, hay cuentos en que la presentación artística y la finalidad ética se equilibran sanamente. Así, el aleccionador "Mi pariente el Mayor Molineaux", sobre la búsqueda de un padre espiritual que resulta ser un impostor; el patriótico y nacionalista "El anciano campeón"; "El entierro de Roger Malvin",. intensol y trágico; eleviolento "Ethan Brand", quizá un retrato de Herman Melville; y r"La, gran cara de piedra", relato planeado en los Cuadernos con pureza y brevedad, pero sustituido por una narración que ilustra ideas de la posible perfección humana y que no revela un argumento o un personaje. En fin, "La catástrofe del señor Higginbotham" representa a los escasos cuentos donde no hay moraleja ni defensa de tesis alguna, sino un juego mental en que la realidad se vuelve soñada $\theta$ increíble. Sin duda, esta es la mejor vena, la más rica, sorprendente y genial, y a ella pertenece la mayoría de bocetos y proyectos anotados en los Cuadernos americanos, en contraste con las anécdotas de viaje de los cuadernos ingleses, franceses $O$ italianos, donde la imaginación ya no se desboca.

En cuanto a Hawthorne el novelista, sus obras forjan una tragedia cristiana: la acción se dispone en torno a la Caída, y la salvación sobreviene por el conocimiento del Diablo y no de Dios. Lo importante es la aplicación en sus libros de ideas sobre la estructura de la novela y el "romance", géneros que él diferencia- 
ba muy bien, llamándose a sí mismo, entre líneas, autor del segundo género. He aquí su argumentación:

Cuando un autor llama a su obra un Romance, ya no debe añadirse que él reclama una cierta amplitud, tanto para su estilo como para su material, que no hublese reclamado de haber escrito una Novela. La última forma de composición persigue, se presume, una minuciosa fidelidad, no solamente a lo posible, sino a lo probable y al curso ordinario de la experiencia humana. La primera, que, por ser obra de arte debe ceñirse a leyes y que peca si se aleja de las verdades del corazón humano, tiene pleno derecho a presentar esa verdad bajo ciertas circunstancias, escogidas en gran parte por el escritor mismo. Si a él le parece bien, puede manejar su medio atmosférico para apagar o disminuir las luces, y profundizar y enriquecer las sombras del cuadro. Será sabio, sin duda, para no abusar de estos privilegios y especialmente para ofrecer lo Maravilloso como un sabor ligero, delicado y evanescente, y no como parte de la sustancia del plato ofrecido al público."

Todo examen, pues, de novelas como La letra escarlata, La casa de los stete tejados, El romance de Blithedale y El fauno de mármol, debe captar este elemento sobrenatural y maravilloso que organiza las novelas y domina la subconsciencia de los torturados personajes, seres que parecen nacidos de Poe, Melville o Faulkner. Jorge Puccinelli Converso»

Si volvemos a los bocetos y argumentos, tal como dice Borges, muy afecto a Howthorne, aquéllos se dividen en dos grupos, según enseñen o no una moraleja. En el primer grupo estaría éste: "Que, despierto y ocupado, un hombre piense muy bien de otro y deposite en él su confianza; pero que lo inquieten sueños donde vea como enemigo mortal a este aparente amigo. Se descubre al fin que el carácter soñado es el verdadero. Esto se explicaría por la percepción instintiva del alma". Pongamos otro - no ya los citados por el argentino- en el mismo grupo: "Que una persona cace moscas de fuego y trate de avivar con ellas el hogar. Que esto simbolice algo". Y todavía un tercero, de sutil intención mo-

*** Ver la Introducción a The House of Seven Gables. Citado en Ray B. West Jr. y Robert Wooster Stallman, The Art of Modern Fiction (New York: Rinehart, 1959), p. 3. 
ral: "Una persona escribe un cuento y ve que éste se forma en contra de sus proyectos; los personajes actúan de otro modo que el planeado; ocurren hechos imprevistos; y sobreviene una catástrofe que en vano trata de desviar. Este cuento puede prefigurar su destino: él se ha pintado en uno de los personajes." En el segundo grupo vemos, según Borges, las fantasías puras, que no buscan justificación o moralidad. Tomemos nuestros ejemplos: A) "Un hombre que en un sitio vive una vida malsana y al mismo tiempo una vida devota y virtuosa en otro." B) "Un viejo espejo. Alguien halla el secreto de hacer que todas las imágenes que se han reflejado en él pasen de nuevo por la superficie." C) "Que se cuenten historias de la aparición en público de un hombre, de cómo ha sido descubierto varias veces, y de sus visitas privadas; pero que finalmente, al buscarlo, se halle su vieja tumba cubierta de musgo." Fantasías como las tres últimas, que aspiran a una descripción profunda de lo real, y donde lo imaginario es ènteramente posible, llenan a raudales los Cuadernos y se hallan mejor como bocetos, que revestidas por el lenguaje fatigado y ceremonioso de los cuentos. Por cierto que hay innumerables combinaciones entre los dos grupos.

La clasificación de Borges es apta, asimismo, para señalar la estructura de los argumentos, partidos como se ven en dos miembros, el uno, expositivo yeel otro, de resumen moral o ideológico. Así, los más bellos carecerían del último miembro. En ambos casos, sin embargo, el fundamento de ellos, tomen la forma de ideas o metáforas, es la pugna entre lo angélico y lo demoníaco, aunque sin duda están en mayoría los bocetos que algunos lectores gazmoños llamarán macabros y aun sangrientos. Para Horwthorne, esa pugna explica la naturaleza humana o tal vez sea en sí misma dicha naturaleza. Aquel hombre cristiano y calvinista creía en el pecado original, en la predestinación y el castigo a los culpables en una "vida futura". Para quienes no creemos en tales cosas, es una honda impresión ver de nuevo en literatura los infinitos y enigmáticos problemas de una conciencia religiosa que, muy de rato en rato, cede ante un Hawthorne travieso, capaz de hacernos sonreir: "Que dos amantes, u otras personas - dice un boceto-, envueltos en el asunto más privado, se citen en un lugar según ellos solitario, y que lo hallen apiñado de gente." Y también sonreiremos con otro: "Que una persona muy imaginativa sea al morir enterrada en una nube." 
La minuciosa lectura de estos argumentos reemplaza con ventaja la figura del Hawthorne implacable y severo, que se negó a conocer a George Eliot (seudónimo de la novelista Mary Ann Evans), debido a que ella vivía con un hombre con el cual no estaba casada, y que odiaba las estatuas desnudas, por la de un creador y poeta cuya imaginación fue enriquecida por su temperamento de ermitaño, temperamento que es objeto de patéticos bosquejos como éste: "Un recluso como yo, o un prisionero, que mida el tiempo por la marcha del sol en su aposento." Su preocupación formal por el cuento, capaz de ganar aplausos de Poe, su propio rival; su cauteloso lenguaje; su gran riqueza imaginativa, hoy confirmada por demás; y los penetrantes análisis de personajes y ambientes en las novelas, rescatan para bien de nosotros al artista Hawthorne, que puede ser exhibido como el antecedente literario de muchos temas y autores.

En efecto. El antecedente del wildeano Retrato de Dorian Gray está aquí: "Simbolizar una enfermedad moral o espiritual por medio de la enfermedad del cuerpo; así, cuando una persona cometa un pecado, que aparezca una úlcera en el cuerpo. Dar forma a esto." El antecedente de algún postulado de Joyce, quien deseó escribir un sueño como un sueño, está igualmente aquí: "Escribir un sueño que se parezca al curso real de un sueño, con toda su inconsistencia sus excentricidades / y su falta de objetivos -si bien con una idea principal a través de todo. Hasta la vieja edad actual del mundo, no se ha escrito tal cosa." Hawthorne anticipa el personaje autónomo de Pirandello, personaje tan viejo como la literatura misma: "Una persona escribe un cuento y ve que éste se forma en contra de sus proyectos... etc." El ser-para-otro de Jean-Paul Sartre fue entrevisto por Hawthorne en esta forma: "La extraña sensación de un hombre que se siente a sí mismo como un objeto de profundo interés y observación... por parte de otra persona". Una técnica semejante a la de Gide y Huxley, de usar personajes que sean novelistas dentro de las novelas que animan, fue experimentada en el cuento "Los siete vagabundos", y en la colección Twice Told Tales, que originalmente deseó titular El narrador de cuentos, a fin de pintar las aventuras de un novelista viajero.

En el resto, hay la ilimitada vena fantástica aprovechada por escritores imaginativos y esteticistas, vena donde caben todas 
las coincidencias entre países y épocas diferentes. * * Inclusive, sin saberlo, por supuesto, jóvenes cuentistas latinoamericanos han empleado temas de Hawthorne. El chileno Guillermo Blanco, en Misa de réquiem, nos da el trágico monólogo interior de un cura que ve entre sus fieles al criminal que ha de matarlo; menos efectista, Hawthorne anotó este proyecto: "Las reflexiones de un Padre Confesor sobre el carácter y el contraste entre el hombre social y el hombre íntimo, a medida que observa $\alpha$ su grey, cuyos pecados secretos conoce." El peruano Julio Ramón Ribeyro, en sus comienzos kafkianos, despliega en el cuento "La huella" un tema de Hawthorne: "El rastro de sangre de un pie desnudo, perseguido por las calles de un pueblo." $Y$ en fin, el eterno deseo de volver sobre los mitos y cuentos de hadas, y actualizarlos, fue también afán de Hawthorne, a quien hasta llegó a acusársele de darle sabor bostoniano a los mitos griegos, en Cuentos de un bosque enmarañado y el Libro de maravillas.

Estos sueños, alegorías y símbolos fueron para Henry James un juego libre y espontáneo, como el movimiento de la superficie del mar. Ojalá esta publicación nos haga compartir el excelente gusto literario de James.

\section{Biblioteca de Letras "Jorge Puccinelli Converso"}

**** Esto no se aplica al poeta mexicano Octavio Paz, quien se valió directamente de "La hija de Rappacini" para escribir en 1956 una pieza de teatro. 


\section{CUADERNOS AMERICANOS}

1835.

Tema para un cuento: algún incidente que pueda causar una vasta guerra y que sobre el culpable recaiga una pena proporcional al daño causado.

Dar el bosquejo de un reformador social moderno -un extremista en asuntos de esclavos y demás tópicos. Pronuncia elocuentes discursos en las calles y está por ganar muchos adeptos cuando es interrumpido por el guardián del manicomio de donde ha huido. Puede explotarse muy bien esta idea.

\section{Biblioteca de Letras}

El cambio deguna muchacha alegresen una mujer vieja: los sucesos melancólicos cuyos efectos se han concentrado en su carácter y gradualmente lo han sometido, hasta hacer de ella una amante de habitaciones enfermizas, que goza al respirar el vaho de los moribundos y al enterrar a los muertos; y que tiene la cabeza llena de recuerdos fúnebres y conoce más seres debajo que encima de la tierra.

Una serie bien ordenada de hechos que cae en la confusión por alguna circunstancia puesta fuera de lugar, insospechada hasta el momento de la catástrofe, pero que ejercía su influencia desde el principio hasta el fin.

Un cuento en que el héroe sea capaz de fuertes y hondas pasiones y espere el tiempo en que viva un apasionado amor, el cual 
será el acontecimiento más grande de su existencia. Pero él no se enamora nunca, y si bien renuncia a este anhelo y se casa tranquilamente, lo hace con alguna tristeza y llevado por sentimientos de mera estimación por su novia. La dama puede ser una que amó tempranamente en su vida y que desdeñó en busca de aquel apasionado amor.

La escena de un cuento o una estampa bajo la luz de un farol callejero; la hora, cuando el farol se apaga; y que la catástrofe sea simultánea con el último resplandor.

La historia de un hombre frío y de corazón duro que no reconoce parentesco alguno con la humanidad. A su muerte tratan de abrirle una tumba, pero a corta distancia bajo el suelo hallan una roca, como si la tierra se negara a recibir en su seno al hijo antinatural. Después lo ponen en un viejo sepulcro, donde ataúdes y cadáveres son ya de polvo, y así lo dejan solo. Luego se petrifica; y habiendo muerto con alguna expresión característica, parecerá, a través de infinitas edades de muerte, repeler la sociedad como lo hizo en vida, y ya nadie podrá ser nunca enterrado en esa tumba.

\section{"Jorge Puccinelli Converso"}

En una vieja mansión puede oirse un toque misterioso en la pared, ahí donde antes había una puerta, hoy amurallada.

Un joven que gana el amor de una muchacha sin intenciones serias y halla que en ese amor (que pudo ser la bendición de su vida) sólo ha conjurado el espíritu del mal que lo persigue durante toda su vida -y esto sin que haya ningún propósito de venganza por parte de la muchacha abandonada.

Que dos amantes, $u$ otras personas, envueltos en el asunto más privado, se citen en un lugar según ellos solttario y que lo hallen apiñado de gente. 
Hacer de la imagen de uno mismo en el espejo el tema de un cuento.

En un sueño, vagar por algún sitio donde puedan oirse las quejas de todos los desdichados de la tierra.

Alguien se cree a sí mismo el principal actor de ciertos hechos notables, pero descubre que sus acciones no han contribuido en nada a ellos. Sin sospecharlo, otra persona es la causante.

Una persona o familia desea por mucho tiempo un bien dado. Éste llega al fin en tal profusión que se vuelve la mayor desgracla de sus vidas.

Una persona escribe un cuento y ve que éste se forma en contra de sus proyectos; los personajes actúan de otro modo que el planeado; ocurren hechos imprevistos; y sobreviene una catástrofe que en vano trata de desviar. Este cuento puede prefigurar su destino: él se ha pintado en uno de los personajes.

Cuatro preceptos: Transgredir las costumbres, remover a los espíritus mal dispuestos, meditar sobre la juventud, no hacer nada contra el "genio de uno mismo.

En este infeliz aposento se ganó la FAMA (Salem, Calle de la Unión). ${ }^{1}$

Una serpiente llevada al estómago de un hombre y alimentada ahí desde los quince hasta los treinta y cinco años, atormentándolo en forma horrible. Una clase de envidia o alguna otra pasión malsana.

Instaurar una nueva clasificación de la sociedad. En vez de ricos y pobres, altos y bajos, clasificarlos así. Primero, según los

1 Hawthorne nació y vivió mayormente en Salem, Massachusetts. 
sufrimientos: por ejemplo, cada vez que los haya, sea en una bella mansión o en una covacha, quienes sufran por la pérdida de amigos y parientes, quienes se vistan de duelo, sea burda o fina la tela que usen, han de formar una clase. Segundo, todos los que sufran por las mismas enfermedades, sea que reposen bajo canopias de damasco, sobre tarimas de paja, o en salas de hospitales, han de formar una clase. Tercero, todos los culpables de los mismos pecados, sean éstos conocidos o no por el mundo; ya languidezcan en prisión, ya aguarden las galeras, o ya deambulen honrados entre los hombres, ellos también forman una clase. Luego, proceder a generalizar y clasificar por igual a todo el mundo, pues nadie reclama una completa exención de un sufrimiento, una enfermedad o un pecado; y si lo hace, entonces la Muerte, como una madre gigante, llega y barre a todos por un oscuro portal. Todos son sus hijos.

La Fortuna llega como un vendedor con sus mercancías: guirnaldas de laurel, diamantes, coronas; las vende, pero pide a cambio el sacrificio de la salud, de la integridad, quizá de la vida en el campo de batalla, o de los nobles placeres de la existencia. ¿Quién las compraría si tuviera que pagar al contado?

Los varios aspectos báa los cuales la Ruina se aproxima a sus víctimas: al mercader en la forma de otro mercader que lo tienta a cometer una especulación; al joven heredero, una grata compañía; a la doncella, un amante dulce y sentimental.

Meditar, conforme se pone el sol, en los sucesos del día. Sucesos ordinarios: por ejemplo, los relojes han dado las horas $y$ los muertos han sido enterrados.

Un recluso como yo, o un prisionero, que mida el tiempo por la marcha del sol en su aposento.

¡La Famal Puede decirse que la poseen ciertas personas humildes en un pueblo - el empleadillo, el pregonero, el policía, bien conocidos por todos-, en tanto que muchas personas más ricas, más intelectuales y valiosas, son desconocidas para la mayoría de sus compatriotas. Sucede algo semejante en todo el mundo. 
Pintar una familia virtuosa con diferentes miembros, cada cual un ejemplo de predisposición a la virtud; luego, introducir una persona viciosa y observar las relaciones que surgen entre ella y los demás, y la forma en- que se influyen todos.

¿Qué haría un hombre si fuera obligado a vivir para siempre en la ardiente brasa de la sociedad y no se bañara nunca en el fresco aislamiento?

El amante de una joven es muerto y sepultado en el jardín de flores que ella posee, y es cubierto por la tierra. Aquel preciso lugar, que ella planta con una escogida variedad de flores, las hace crecer con admirable belleza, esplendor y perfume; y la joven se deleita y siente un indescriptible impulso de lucirlas en el pecho y de perfumar con ellas su alcoba. Así, el clásico cuento de hadas podría cumplirse, el de los muertos convertidos en flores.

Exhibir el efecto de la venganza cumplida. Suponed, por ejemplo, a una mujer que enjuicia a su amante por el rompimiento de la promesa $y$ obtiene el dinero a plazos, durante muchos años. Por fin, cuando la pobre víctimavesté Carruinada, la vengadora se habrá convertido en un demonio de pasiones malsanas - Y éstas habrán dominado toda su naturaleza, de modo que sobre ella se haya cernido un mal mucho mayor que sobre su víctima.

Que nuestro cuerpo sea poseído por dos espíritus diferentes; que una mitad del rostro exprese un estado de ánimo, y la otrá el segundo.

Un hombre rico lega por testamento su mansión y sus bienes a una pareja pobre. Esta se muda y halla en la mansión a un sombrío mayordomo a quien no puede echar según el testamento. El los acosa y por fin se sabe que es el antiguo dueño de la mansión. 
Que dos personas aguarden un acontecimiento y la llegada de los dos principales actores, y que descubran que el suceso ya está ocurriendo y que ellos mismos son los actores.

En todo corazón humano existe el mal, que quizá puede permanecer latente de por vida; pero las circunstancias pueden activarlo. Imaginar dichas circunstancias. Una mujer tentada de engañar a su marido sólo por capricho, o un joven que siente una instintiva sed de sangre y comete un crimen...

Los buenos actos en una vida maldita - los generosos, nobles y excelentes actos cumplidos por gente habitualmente viclosa: preguntarse qué será de ellos.

Un artículo sobre el fuego, sobre el humo. Enfermedades de la mente y el alma -todavía más comunes que las del cuerpo.

1837.

Un joven y una muchacha se reúnen mientras cada cual busca a una persona reconocibleiporlalgún señuelo. Vigilan y esperan mucho rato a que pase. Por fin alguna casualidad revela que cada uno es la persona que el otro espera. Moraleja: lo necesario para la felicidad está a menudo al alcance de nuestras manos, si sólo supiéramos cómo buscarlo.

Un día en el diario de un corazón humano bajo circustancias normales. Las luces y sombras que lo atraviesan; sus vicisitudes internas.

Ejemplificar así la desconfianza. Que se presenten muchas cosas buenas y deseables ante un joven, y que se ofrezcan para su aceptación: digamos, un amigo, una esposa, una fortuna; pero que él las rechace todas creyendo que son una ilusión. No obstante, que todas sean reales y que así lo sepa ya tarde. 
Un hombre busca ser feliz en el amor, pero sinceramente no puede dar su corazón y el idilio le parece un sueño. En la vida doméstica le ocurre igual; en política, no es un patriota de verdad. Pero él continúa siendo sincero, y todo es como en el teatro.

Los placeres, ocupaciones y pensamientos de un vagabundo en un día frente al mar: en medio de ellos, el sentarse en lo alto de un precipicio y echar piedras abajo, a su propia sombra.

Juzgar buenamente los caracteres de los miembros de una familia bajo una cieria condición - digamos, la pobreza- y esforzarse en juzgar cómo otra condición afectaría el carácter de cada uno de ellos.

Una persona consciento de que va a morir pronto, en el ánimo de visitar por úlima vez a gentes y cosas amigas.

Que una persona esté en posesión de algo tan perfecto como el hombre mortal tiene derecho a pedir; buscar hacerlo aún mejor y lo arruina por completo.

\section{blolloteca de Letras \\ "Jorge Puccinelli Converso"}

Que una persona gaste su vida y talento en conseguir algo naturalmente imposible -digamos, conquistar la Naturaleza.

Meditaciones sobre el servicio de gas de una gran ciudad - ¿qué pasaría sí el abastecimiento fuera interrumpido? ¿Cuántas escenas diferentes provocaría? Esto puede ser alegórico.

La insinceridad en el corazón de un hombre vuelve irreales todos sus placeres e intereses; de modo que toda su vida se asemeja a una simple representación teatral, aunque esté rodeado de parientes y amigos veraces.

Que un cuento muestre cómo todos estamos errados y somos pecadores, y nos vengamos unos de otros. 
Un hombre que en un sitio vive una vida malsana y al mismo tiempo una vida devota y virtuosa en otro.

Un adorno para ser usado por una dama, tal como una joya en forma de corazón. Después de muchos años se rompe o se abre y deja escapar un olor ponzoñoso.

Varias personas beben cierta medicina, que puede ser un veneno o un remedio, según los diferentes caracteres de ellas.

Una nube en forma de una vieja y arrodillada mujer extiende los brazos a la luna.

Un viejo espejo. Alguien halla el secreto de hacer que todas las imágenes que se han reflejado en él pasen de nuevo por la superficie.

Los hombres de frías pasiones tienen ojos vivaces.

Una muchach ivirtuosa, aunque voluble, desea tenderle una trampa a un hombre. Éste lo sabo y planea los hechos en tal forma que ella se abandona a su poder y se arruina... Todo es en broma.

Que un horrendo secreto se divulgue entre personas de diversos caracteres, graves o alegres, y que, de acuerdo a ellos, todas terminen locas por obra del secreto.

Que se cuenten historias de la aparición en público de un hombre, de cómo ha sido descubierto varias veces, y de sus visitas privadas; pero que finalmente, al buscarlo, se halle su vieja tumba cubierta de musgo.

El influjo de una rara mentalidad, en estrecha relación con otra a fin de enloquecerla. 
1838.

La situación de un hombre en medio de la multitud, pero cuya vida está del todo en manos de otro, como si ambos estuvieran en el desierto.

Sucesos extraños, misteriosos y terroríficos destruyen la felicidad de un hombre, quien los achaca a varias personas y causas, pero finalmente sabe que el único responsable es é!. Moraleja: la felicidad depende de nosotros mismos.

El curioso incidente en la corte del rey Carlos IX de Francia. Éste y otros cinco enmascarados, con túnicas ungidas de brea y flecos de lino pegados a ellas, a fin de representar a unos salvajes peludos, entran bailando en el salón, todos amarrados y con el rey en primer término. Pero debido a un accidente, una cntorcha les prende fuego. Dos de ellos mueren quemados en el sitio, dos mueren más tarde, y el otro huye a la despensa y se arroja a un depósito de agua. La escena puede prefigurar el destino de un puñado de hombres disolutos.

Memorandumbli En camino a Torthampton, pasamos a un manso cuervo que se veía én do alto de uns granero. El cuervo dejó su puesto y nos siguió un buen trecho, jugando por el camino y volando con sus alas negras, flexibles y grandes, de un poste a otro en la valla, y de árbol en árbol. Tal vez correctamente, el cochero dijo que el cuervo había olido el salmón de una cesta bajo el asiento y que por eso nos seguía. Esto podría ser horrendo si el cuervo hubiera olido un cadáver y no la cesta de salmón. Suponed, por ejemplo, que en un coche en marcha uno de los pasajeros muera de pronto y que una de las señales de su muerte sea el vuelo del cuervo.

Que al parecer la máquina a vapor de una fábrica posea un genio maligno; coge el brazo de un hombre y se lo arranca; atrapa los faldones de la chaqueta - y casi el cuerpo- de otro; ase el pelo de una muchacha y le arranca el cuero cabelludo; y por fin arrastra hacia sí a un hombre y lo despedaza mortalmente. 
Que en un lago resuciten todos los muertos que hayan sido ahogados.

Una señal de otoño: los niños han juntado en la calle las hojas caídas de los olmos y han hecho una gigante pila, y en ésta un hueco en forma de nido, en el cual tres o cuatro de ellos, de rizado pelo, yacen como tiernos pájaros.

La naturaleza de un hombre absolutamente falso por dentro y por fuera; que su fortuna descanse en un crédito sin fondos, que su patriotismo sea fingido, y que todos sus vínculos domésticos, su honor y su probidad sean un engaño. $Y$ en medio de ello, su propia miseria que hace de todo el universo, del cielo y la tierra, una insignificante mueca de sí mismo.

La penitencia del Dr. Johnson/en el mercado de Utoxeter. Un hombre que pena en la época más gloriosa y triunfal de su vida, según observadores superficiales. Cada etapa en la carrera de un hombre de aparente éxito es una tortura y una penitencia para él, debido a un error fundamental en su juventud.

Que una persona cace moscas de fuego y trate de avivar con ellas el hogar. Que esto simbolice-algo.

Que, despierto y ocupado, un hombre piense muy bien de otro y deposite en él su confianza; pero que lo inquieten sueños donde vea como enemigo mortal a este aparente amigo. Se descubre al fin que el carácter soñado es el verdadero. Esto se explicaría por la percepción instintiva del alma.

La caja de Pandora en un cuento de niños.

La luz de la luna es escultura; la del sol, pintura.

H. L. C- oyó de un franco-canadiense el cuento de una joven pareja en Acadie, en su día de bodas. Todos los hombres 
de la provincia fueron convocados a una asamblea en la iglesia, a fin de oir la proclamación. Una vez reunidos, fueron capturados y embarcados, inclusive el novio, hacia diversos puntos de Nueva Inglaterra. La novia partió en busca de aquél y recorrió durante toda su vida Nueva Inglaterra, y finalmente, ya vieja, lo halló en su lecho de muerte. La impresión fue tan honda que ella murió también. ${ }^{2}$

1839.

Cuando dispersas nubes descansan en los pechos de las montañas, es como si uno pudiera subir a la región celestial, a causa de la tierra entremezclada con el cielo y gradualmente transformada en él.

Un desconocido es enterrado al morir y después de muchos años llegan dos desconocidos en busca de su tumba y la abren.

La extraña sensación de un hombre que se siente a sí mismo como un objeto de profundo interés y observación, y aun de ingerencia en sus acciones, por parte de otra persona.

\section{«Jorge Puccinelli Converso»}

Que una persona muy imaginativa sea al morir enterrada en una nube.

"Una historia se contaba de un rey de la India que envió a Alejandro una hermosa mujer alimentada con acónito y otros venenos, para destruirlo fisiológicamente, ya sea por medio de la plática o de la copulación." Sir T. Browne.

Un aciago síntoma en una persona que pierde su aspecto individual y toma los rasgos de su familia, ocultos en el saludable

2 Este es el argumento de "Evangelina". Hawthorne lo traspasó a Longfellow, diciendo que su amigo haría mejor uso de él. Nota de Malcolm Cowley. 
rostro. Quizá un investigador pueda así reconocer al hombre que buscaba, después de tratar mucho con él.

Tener hielo en la sangre.

Tejer un cuento con todas las cosas imposibles y extrañas como la Salamandra o el Ave Fénix.

Que las líneas de un rostro humano se dibujen en la falda de una montaña $o$ en la grieta de una pequeña pledra, debido a un lusus naturae. Por años y siglos el rostro es objeto de curiosidad; y luego nace un niño cuyos rasgos lo imitan gradualmente. El parecido se completa en un momento dado. Que haya en esto una profecía. ${ }^{3}$

Que una persona cause la muerte de su amada por elevarla a una perfección sobrenatural; pero que esto sea para él un alivio por haber ansiado tan beatíficamente.

$1840-1841$.

\section{Biblioteca de Letras}

Un hombre desconocido y qentado por secretos crímenes deja en la iglesia una nota, implorando las oraciones de la congregación.

Exhibir en lugares públicos algo muy secreto, valioso y querido entre dos amantes, y que toda la ciudad hable de él-que haya críticas, mofas y burlas.

Representar a un hombre que malgasta su vida y sus mayores trabajos en la invención de una tontería mecónica: fabricando un coche en miniatura que será tirado por moscas o un servicio de comedor para ser colocado en el hueso de una cereza.

3 Argumento de "La gran cara de piedra". 
Encender una hoguera con las horcas y demás símbolos del mal.

El amor a la posteridad es resultado de la necesidad de la muerte. Si un hombre estuviese seguro de vivir para siempre, no se ocuparía de su linaje.

Un fantasma de los viejos gobernadores reales, o alguna indefinida procesión triunfal, en la noche de la evacuación de Boston por los ingleses.

El egoísmo es una de las cualidades que inspiran el amor. Ampliar mucho este pensamiento.

Simbolizar una enfermedad moral o espiritual por medio de la enfermedad del cuerpo; así, cuando una persona comete un pecado, aparece una úlcera en el cuerpo. Dar forma a esto.

Un hombre de juicio recto: hay en él un sentimiento de lo verdadero y lo falso que puede representarse por el talismán con que, en los cuentos de hadas, un aventurero distingue las realidades de loseencantamientos.i Converso"

\section{2-1843.}

Que un hombre de voluntad poderosa ordene a otro, moralmente sujeto a él, realizar un acto. El primero muere de súbito, mas la persona sometida continúa realizando ese acto por el resto de su vida.

Estudiar el influjo de un crimen aterrador y desdichado que arruina y rebaja a una persona eminente y noble -ésta es la persona culpable, la única en saber dicho crimen.

Un hombre que traga una pequeña serpiente —el símbolo del pecado deseado. 
Que una persona hipnotizada formule preguntas tales como discutibles hechos históricos o misterios de la Naturaleza.

Un repentino brote de violetas en un sendero.

Enfermedades imaginarias curadas por remedios imposibles - una dosis del Gran Elixir en la yema de un huevo del Ave Fénix. Las enfermedades pueden ser físicas o morales.

Las reflexiones de un Padre Confesor sobre el carácter y el contraste entre el hombre social y el hombre íntimo, a medida que observa a su grey, cuyos pecados secretos conoce.

Una persona de mano fría (la derecha) como el hielo, recordada siempre por la gente que se la estrechó una vez.

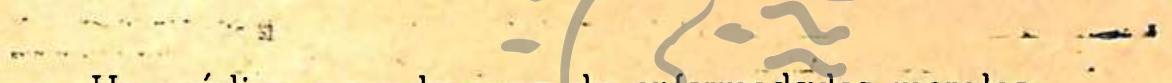

Un médico para la cura de enfermedades morales.

El caso de Pinel citado en la Psicología de Combe, sobre un joven de talento y de profundos conocimientos de química, en vísperas de un importante descubrimiento. A fin de dar a su mente la mayor actividadoposible se enecerró por muchos días y usó diversos medios de excitación: tenía consigo a una muchacha cantante, bebía licores espirituosos, olía penetrantes olores, rociaba de agua de colonia su habitación. Así transcurrió una semana y fue presa de un ataque que lo volvió maniático.

Una hoja extraviada del libro del Destino, recogida en la calle.

Un filósofo moralista compra un esclavo o entra de algún modo en posesión de un ser humano, y lo emplea como conejillo de Indias a fin de curar un vicio propio.

Al completarse la renovación del mundo, las horcas arderán en el fuego y el Ahorcado vendrá y se sentará junto a él, des- 
consolado y huérfano. Hacia él irán el último Ladrón, la última Prostituta, el último Borracho, y otros representantes del crimen y el vicio del pasado; y todos animarán una lúgubre fiesta, bebiendo a cántaros la última Botella de Aguardiente del Borracho.

Simbolizar en una caverna el corazón humano. Por la entrada hay sol y las flores crecen en torno a ella. Luego pasáis adentro y a corta distancia empezáis a veros en medio de una macabra oscuridad y de muchas clases de monstruos; os parece el Infierno. Os perdéis y vagáis largo tiempo, sin esperanza. Por fin os envuelve una luz. Merced a ella os veis en una región que de algún modo reproduce, ya perfectas, las flores y el bello sol de la entrada. Éstas son las profundidades del corazón, de la naturaleza humana, brillantes y apacibles. Las tinieblas y el temor pueden yacer abajo; pero más abajo aún está la belleza eterna.

La señora Calderón de la Barca se refiere en su Vida en Méxl$\mathrm{co}^{4}$ a hombres inoculados con el veneno de culebras de cascabel, una vez mordidos en diversas partes del cuerpo. Estos hombres quedan inmunes a todo veneno de reptiles. Tienen el poder de llamar a las culebras y sienten hondo placer al jugar con ellas y manosearlas. Su propla mordedura es venenosa para los no inoculados. Assí, una parte de loonturaleza de la serpiente ha transfundido a ellos.

Una joven hereda un cementerio familiar - lo único restante de sus ricas posesiones.

El rastro de sangre de un pie desnudo, perseguido por las calles de un pueblo.

Ejemplificar la majestad de la muerte con un mendigo que tras haber sido visto durante muchos años, bajo y humilde, en las calles de una ciudad, por fin, de un modo u otro, es admitido en

4 Libro publicado en 1843. 
la mansión de un hombre rico y muere ahí usurpando un sitial y sembrando el temor en quienes lo habían desdeñado.

Escribir un sueño que se parezca al curso real de un sueño, con toda su inconsistencia, sus excentricidades y su falta de objetivos; si bien con una idea principal a través de todo. Hasta la vieja edad actual del mundo, no se ha escrito tal cosa.

Simbolizar la vida por medio de una mascarada y presentar enmascarados a los hombres. Aquí y allá puede verse un rostro natural.

Bosquejar un personaje con la malignidad de una bruja que cometa los males atribuidos a ella, pero por medios naturales: deshace amores, enseña vicios a los niños, arruina a los hombres de fortuna, etc.

Con una simbólica varita divina buscar el oro simbólico -0 sea la Verdad, lo celestial en la tierra.

\section{Biblioteca de Letras}

Que unos hombres perversos dejen sus guaridas en una ocasión favorable; hasta entonces nadie los conocía. Por ejemplo, la Revolución Francesa obligó a salir a tales indeseables.

Las ventajas de una vida más larga que la concedida a los mortales; las muchas cosas que podrían realizarse, para las cuales una vida es insuficiente, y el tiempo gastado en ellas, perdido. Un sucesor sería incapaz de prosegir la tarea interrumpida per nosotros.

La historia de un asilo en una aldea, desde el día de su fundación - un registro de sus principales ocupantes y extractos de novedosas partes de sus anales. Una segunda generación de ricos puede buscar ahí un hogar, ya sea por medio de sí mismos o de sus representantes. Quizá el hijo y heredero del fundador no 
halle mejor refugio que ése. Pero debe dejarse algún rayo de sol en el cuento; digamos, la buena estrella de algún niño sin nombre, educado ahí, y que al fin resulta ser un hijo de padres ricos.

Perla -el nombre inglés de Margarita-: un bello nombre para la muchacha de un cuento. ${ }^{6}$

Un hombre busca algo excelente por vía y humor falsos y se da con algo horrendo - si, por ejemplo, busca un tesoro, halla un cadáver en vez del oro escondido, y así se iluminan sus varios pecados.

El Mágico Juego de la Luz del Sol, en un cuento para niños: la luz del sol cae de una alto y estrecha ventana y se pasea por la celda de un prisionero. Éste mantiene vivo su ánimo y su espíritu por aquella señal de alegría; cuando es libertado, coge el rayo de sol y se lo lleva consigo, y el rayo le permite descubrir tesoros en toda la tierra, en sitios donde ningún otro los buscaría.

Para la colección del Virtuoso: la pluma con que Fausto firmó su salvación, ý en ella una secá gota dé sangre."

En horas de gran desaliento, uno cree en la dicha de hundirse en algún rincón apacible y quedar allí para siempre, dejando que la tierra se acumule poco a poco y forme sobre nosotros una colina, y que en ella crezcan hierbas y quizá flores. En tales momentos, la muerte es demasiado para ser querida - nos falta el ánimo de enrostrarla. Pero, como sea, tratad de salir de esta indolencia.

5 Perla será hija de Hester Prynne, heroína de La letra escarlata. Su retrato parece basado en las observaciones del autor sobre su hija Una.

6 En el volumen de cuentos Mosses from an Old Manse (1846) aparece el titulado "La colección del virtuoso". 
El sueño de la otra noche, en que el mundo, insatisfecho del falso modo en que se cuentan las cosas, me había contratado por un sueldo de mil dólares a fin de contar exactamente como suceden los hechos públicos.

Una persona que tiene todas las cualidades de un amigo, excepto que invariablemente os falla en un aprieto.

$1844-1846$.

Ejemplificar nuestra visión adulta de los proyectos e ilusiones de la adolescencia, por medio de una persona mayor que deambula a través de los muchos castillos en el aire, soñados en su juventud, y describir qué le parecen - su destrucción, etc. Es posible que algunos sean reales y le basten para erigir una humilde morada donde pasar su existencia.

La búsqueda por un investigador del Pecado Imperdonable: lo halla por fin en su corazón y sus costumbres.

\section{Biblioteca de Letras}

Los árboles reflejados en el río inconscientes del mundo espiritual que los rodea. Así somos nosotros.

El Pecado Imperdonable pudiera consistir en un deseo de amor y reverencia por el Alma Humana; debido a esto el investigador observa sus tenebrosas profundidades, no para mejorarla, sino por una fría y filosófica curiosidad, dichoso de que sea malvada y deseando tan sólo examinarla. En otras palabras: ¿no sería esto la separación del intelecto y el corazón??

Representar el influjo de los Hombres Muertos en las cosas vivas. Por ejemplo, un Hombre Muerto gobierna la distribución

7 Este "Pecado Imperdonable" se exhibe en el corazón del héroe Ethan Brand y es el fundamento ideológico de novelas como El romance de Blithedale y El fauno de mármol. 
de la riqueza; un Hombre Muerto se sienta en el sitio del juez y los jueces vivos actúan, pero respetan las decisiones de aquél; las opiniones de los Hombres Muertos gobiernan por todas partes la verdad de los vivos. Creemos en la religión de los Hombres Muertos; reímos de las bromas de los Hombres Muertos; lloramos por las penas de los Hombres Muertos; donde sea y como sea, los Hombres Muertos inexorablemente tiranizan sobre nosotros.

Bosquejar a una persona que debido a la fuerza de su carácter o a circunstancias favorables reduce a otra a esclavitud y dependencia absolutas. Luego, mostrar que el supuesto amo es inevitablemente tan esclavo como el otro, si no más. Toda esclavitud es recíproca, en el mejor supuesto de quienes mandan.

De quienes, como Byron, escriben sobre sí mismos y sobre sus sentimientos, puede decirse que sirven como refrigerio al público sus propios corazones, muy bien condimentados, y con una salsa cerebral extraída de sus cabezas.

Representar a un hombre en medio de toda clase de molestias y cuitas -con hechos imposibles que realizar- y casi perdido por su imperfección. Luego viene calladamente la Muerte y lo liberta de sus afanes. El sonrie al exhalar el último suspiro, satisfecho de huir tan fácilmente...

La vida de una mujer que según la vieja ley colonial [norteamericana], fue condenada a llevar siempre la letra A cosida a sus ropas, en señal de haber cometido un adulterio. ${ }^{8}$

Ver asomada en los ojos de un niño, o de otra persona inocelite, la imagen de un querubín o de un ángel; y la de un diablo en los de una persona viciosa.

8 Elemento valioso para La letra escarlata. Desde el cuento "Endicott y la cruz roja" (1837), a Hawthorne le inquietaba un emblema, o faja roja, llevado por una mujer. 
Los católicos creían que los niños eran engendrados por las relaciones entre brujas y demonios. Se dijo que Lutero era un bastardo de esta prole infernal.

Los casos de dos damas que juraron no ver más la luz del sol debido a decepciones amorosas. Cada cual mantuvo su promesa y en adelante vivió y murió luego de muchos años, en habitaciones enclaustradas, sin más luz que unas velas. Parece que una de ellas vivió en completa oscuridad.

En un jardín, una piscina de agua transparente cuyo fondo es de baldosas de mármol o quizá de mosaicos: imágenes y figuras se exhiben pasmosamente bellas a través del agua.

1847-1849.

Un cuento sobre los efectns de la venganza al pervertir a quien se entrega a ella.

Un cuento sobre la vida doméstica y social de una familia de pájaros en una casa delgolondrinas etun cuento para niños.

\section{"Jorge Puccinelli Converso"}

Entre los sobrevivientes de un naufragio hay dos enemigos mortales. Habiendo pasado muchos días de hambre, todos deciden por suerte quién será asesinado y comido por el resto. La suerte recae en uno de los enemigos. ¡El otro ya puede comer literalmente su corazónl

Un hombre, después de envejecer al máximo, se transforma de nuevo en un joven, con el mismo ritmo con que ha envejecido; así retorna a su camino, a través de toda la vida, y ve de modo inverso las cosas. Creo que surgirían raros encadenamientos. ${ }^{9}$

9 Boceto aprovechado en "El experimento del doctor Heidegger". 
Sir Walter Raleigh, Sir Thomas More, Algernon Sydney, o algún otro gran hombre, en la víspera de su ejecución, reflexionan sobre su propia Cabeza -examinándola y dirigiéndose a ella ante un espejo.

Un cuento cuyo personaje principal parezca slempre que ha de entrar en escena, pero sin hacerlo nunca.

Un mago moderno hace la réplica de un ser humano con dos palos por piernas, una calabaza por cabeza, etc., empleando materiales rústicos e inadecuados. Luego, un sastre lo ayuda en su obra y transforma al espantajo en una figura de moda... Al fin de la historia, tras engañar al mundo por buen tiempo, el enigma se descifra y el oscuro petimetre es nada más que un traje con los palos debajo. En toda su falsa vida como ser humano, hubo ciertos rasgos, ciertas señas que, ante un hombre observador y sutil, lo traicionaban y exhibían como simple cosa hecha de palos y ropas, sin corazón, alma, ni entendimiento. Y así este objeto miserable será el símbolo de una vasta clase.

Heredar una gran fortuna. Heredar una gran desdicha.

Un rayo de luz del sol que busca un rastro de sangre a través de un cuarto solitario.eca de Letras

\section{Representativorge Puccinelli Converso»}

En un cuento macabro y sobrenatural, la figura de un hombre (o mujer) joven, sonriente, dichoso y bello, que de súbito y de modo descuidado se quita el rostro como una máscara y enseña debajo la mueca del cráneo desnudo.

Una familia compuesta por el padre, la madre y dos niños han salido a pasear y se han sentado en medio de un bosque. La niña oye un llamado, corretea dentro del bosque y vuelve minutos más tarde. Al principio los padres no ven cambio alguno en ella, pero gradualmente empiezan a ver algo raro - lo notan más y más, hasta que, pasando los años, sospechan que quizá otra niña, y no la suya, volvió aquella vez.

Departamento de Literatura Universidad de San Marcos. 